\title{
INFLUENCE OF PHILAZONIT BIOPREPARATION ON THE MYCOBIOME OF SOYBEAN PLANTS RHIZOSPHERE
}

\author{
Alla Parfenuk \\ Doctor of Biological Sciences, Professor ${ }^{l}$ \\ vereskpar@ukr.net \\ Liliia Havryliuk \\ Graduate student ${ }^{1}$ \\ 410agroeco@gmail.com \\ Irina Beznosko \\ PhD in Biological sciences ${ }^{l}$ \\ beznoskoirina@gmail.com \\ Larisa Pasichnik \\ PhD in Agricultural Sciences \\ National University of Life and Environmental Sciences of Ukraine \\ 15 Heroes of Defense str, Kyiv, Ukraine, 03041 \\ pasichnik@ukr.net \\ Yuliia Turovnik \\ Graduate student \\ turovnikylia@gmail.com \\ Yuri Ternovyi \\ Candidate of Agricultural Sciences \\ Skvyra Research Station of Organic Production of the Institute of Agroecology and Environmen- \\ tal Management of NAAS \\ 1 Selection str, Skvyra, Ukraine, 09001 \\ ternowoj@i.ua \\ ${ }^{1}$ Institute of Agroecology and Environmental Management of NAAS \\ 12 Metrologichna str, Kyiv, Ukraine, 03143
}

\begin{abstract}
The article presents the results of analysis of biodiversity and spatial-functional structure of the microbial complex in the soil rhizosphere, and development of ways to regulate the number of phytopathogenic micromycetes in the rhizosphere of soybean plants in organic production. Varieties of plants of soy were grown using the biopreparation «Philazonit", which was developed in the company "Philazonit of Ukraine". The study determined the effect of phylazonite biopreparation on the mycobiome of the rhizosphere of soybean plants. The interaction of plants of soy varieties Kent and Suzir'ja with phytopathogenic micromycetes in conditions of the organic production in the Central Forest-Steppe of Ukraine (Research farm "Skvyrske" of Institute of Agroecology and Nature Management of the National Academy of Agrarian Sciences of Ukraine (IANM of the NAAS) was investigated. The number of phytopathogenic micromycetes in the rhizosphere of plants of different varieties of soy is determined depending on the variety and technology of its cultivation. It was established that the biopreparation Philazonit inhibits the formation of the number of phytopathogenic micromycetes in the rhizosphere of plants of the soy variety Suzir'ja and Kent during the growing season. It is proved that the representatives of genera: Alternaria, Fusarium, Penicillium, Aspergillus are dominated in the rhizosphere of plants of soy of both varieties. In the rhizospheres of plants of the soy Suzir'ja variety the representatives of genus Penicillium (32.8\%) most often occurred. The smallest number of micromycetes were members of the genus Aspergillus (9.5\%). In the rhizosphere of plants of the Kent variety dominated by representatives of the genera Alternaria and Fusarium (35.6\% and $34.1 \%$ respectively). Representatives of the genus Penicillium were $15 \%$ and Aspergillus - $15.3 \%$ It is proved noted that during the studies there was a
\end{abstract}


Keywords: soybeans, phytopathogenic micromycetes, rhizosphere, hydrothermal coefficient, ecology, agrocenosis.

DOI: $10.21303 / 2504-5695.2021 .001874$

\section{Introduction}

Fertile land and favorable climate determined the rapid spread of production of soy in Ukraine. At the same time, there is a growing of the mass accumulation of phytopathogenic microorganisms in the agrocenoses of soy, among which genera: Fusarium, Alternaria, Penicillium, Aspergillus are dominated [1-3]. They lead to the development of harm-causing diseases of soybean plants during the growing season and can intensively inhabit the seed material. This causes a deterioration in the quality of the crop by reducing the indicators of protein and fat contents [4]. These micromycetes are toxin-forming. They can damage of the various organs of plants, animals, fungi and are toxic to humans.

A wide range of phytotoxic action have deuteromycetes toxins, which belong to the genera: Penicillium, Aspergillus and Fusarium. In the functioning of the system (soil - microbial community - plants), toxin-forming micromycetes are characterized by greater competitiveness compared to other microorganisms [5-8].

Therefore, more and more attention is paid to the organic production of soy in the world, which is aimed at regulating the number of phytopathogenic microorganisms in agrocenoses. Biological preparations are one of the most powerful factors in regulating of the biotic relationships in agrocenoses, which allows to solve the issue of ensuring a balanced nutrition of plants and resistance to phytopathogenic micromycetes. Retrospective analysis of literature showed that the problems of the effectiveness of the influence of biological preparations on the functioning of agroecosystems were studied by various scientists [9-15]. Their research revealed the main problems such as: optimization of the nutritional regime under the influence of biopreparations, increasing of the crop yields, reproducing of the soil fertility, regulating their microbiological activity. High efficiency of the various biopreparations using was found, among which Philazonit biopreparation has proven itself.

Philazonit is a complex biopreparation based on beneficial soil bacteria.

Philazonit contains several groups of bacteria: nitrogen-fixing bacteria, phosphate-mobilizing bacteria, celluloso-destroying bacteria. The composition of Philazonit also includes natural B vitamins, which reduce the sensitivity of plants to diseases, as well as hormones that accelerate seed germination and plant growth, in particular gibberellins and auxins. Antipathogenic bacteria prevent and protect plants from fungal diseases, especially Fusarium oxyporum and promote the production of immunity in plants. Soy plants respond well to the introduction of biopreparations that contribute to: the productivity of soy; humic acids enhance the properties of plant immunoregulation, biosynthesis of protective substances; contribute to the growth of auxins and cytoquinins; regulate of the physiological processes in cells [16, 17].

Consequently, soil microbial cenoses have complex genetic and spatial organization and high biodiversity, the structure of which depends on farming systems, agrotechnical measures and physiological biochemical properties of cultivated plants.Therefore, the study of the effect of the biological product Filazonit on biodiversity and the spatial-functional structure of the microbial complex in the soil rhizosphere is important for regulating the number of phytopathogenic micromycetes in the rhizosphere of plants of soy varieties in conditions of organic production.

So, the goal of the investigation was to develop of the ways to regulate the number of phytopathogenic micromycetes in the rhizosphere of plants of soy varieties in conditions of organic production.

\section{Materials and Methods}

\section{1. Characteristics of place, soil of researches}

Experimental research was carried out during 2018-2020 in the Central Forest-Steppe of Ukraine (Research farm "Skvyrske" of organic production of the IANM of the NAAS) and in 
the Department of Agrobioresources and Environmentally Safe Technologies of the IANM of the NAAS. The best soils for soy are black humus earth, dark gray and chestnut. The most suitable for this crop are soils with a neutral reaction ( $\mathrm{pH}$ 6.5-7.0). The soil of the research field of the "Skvyrske" research station of organic production is represented by low-humus black humus earth, and in the mechanical composition - large dusty-medium loamy. The humus content in the upper layer of soil $(0-20 \mathrm{~cm})$ is $3.6 \%$, lightly hydrolyzed nitrogen $-6.6 \mathrm{mg}$, easily digestible phosphorus $-14.0 \mathrm{mg}$ and metabolic potassium $-15.2 \mathrm{mg}$ per $100 \mathrm{~g}$ of soil. The reaction of the soil solution is slightly acidic $(\mathrm{pH}=6.0)$.

\section{2. Hydrothermal coefficient (HTC)}

Hydrothermal coefficient (HTC) was calculated according to the methodology [18].

$\mathrm{HTC}=\Sigma \mathrm{R} / 0,1 \cdot \Sigma \mathrm{t}_{\mathrm{act}>10}$,

where:

HTC $<0.4$ - very strong drought, HTC from 0.4 to 0.5 - severe drought,

HTC from 0.6 to 0.7 - average drought,

HTC from 0.8 to 0.9 - weak drought,

HTC from 1.0 to 1.5 - sufficiently moisture,

HTC $>1.5$ - excessively moisture.

\section{3. The object of the study}

Samples of plants of different varieties of soy were selected during the growing season in the phase: shoots, flowering, maturation. The studies were carried out on plants of soybean varieties: Suzir'ja, selection of the National Scientific Center of the Institute of Agriculture of the National University of Ukraine and Kent variety, selection company "SAATBAULINZ" in Austria. The technologies with using of the biopreparations of various actions is the alternative at the organic production, because the use of mineral fertilizers and plant chemical protection products is prohibited. Therefore, the varieties of plants of soy were grown using the biopreparation "Philazonit", which was developed in the company "Philazonit of Ukraine".

We used a biological product Filazonit before sowing soybeans (tillage). Consumption rate $-1.51 /$ ha.

To compare the results, we used the control option (soybean varieties without processing of the biological product).

The sampling of the biological samples and counting the number of colony-forming units (CFU) were carried out according to methods, generally recognized in mycology [19].

\section{4. Analysis of soil mycobiome}

Analysis of soil mycobiome was carried out by soil dilution method [20]. The rhizosphere soil was taken from the roots of plants. Samples were transferred in laboratory conditions to sterile flasks of $90 \mathrm{ml}$ of sterile distilled water and for 5 minutes were shaken on a horizontal orbital shaker (Wise Shake SHO, SHR 2D) to a homogeneous suspension. $1 \mathrm{ml}$ of suspension was transferred from the flask to a sterile test tube of $9 \mathrm{ml}$ of sterile water. From the test tube of the 3rd dilution, $1 \mathrm{ml}$ of the suspension was seeded into sterile Petri cups. After that, $10 \mathrm{ml}$ of Chapek medium was poured, mixed and incubated at a temperature of $25^{\circ} \mathrm{C}$ for 3 days, after which colonies were counted on the automatic counter SCAN 4000 (Intercience, France) and transferred them into test tubes for further identification.

\section{5. Identification of isolates}

Identification of isolates was carried out on 15-day cultures using a trinocular microscope (DN-200 M) using the Mycobankdatabase base [21]. 


\section{6. The count of colonies}

The average number of colonies of fungi per $1 \mathrm{~g}$ of dry soil was determined by the formula [22]:

$$
A=\frac{b \cdot c \cdot K}{g},
$$

where:

$A$ - the number of infectious units of micromycetes in $1 \mathrm{~g}$ of dry soil;

$b$ - the average number of colonies in a cup;

$c$-dilution of the solution, from which inoculation is made;

$K$ - humidity amendment;

$\mathrm{g}$ - soil weight $(10 \mathrm{~g})$.

\section{7. Statistical analysis}

Statistical analysis of the obtained results was carried out using dispersion and correlation analysis $(p=0,05)$ [23]. For the process of the results, standard mathematical methods of data analysis and charting were used using the Microsoft Office Program Package, Statgraphics Plus for Windows, Excel 2000.

\section{Results}

The air temperature exceeded the norm of indicators during the field research and ranged from $14{ }^{\circ} \mathrm{C}$ to $29^{\circ} \mathrm{C}$ (Fig. 1).

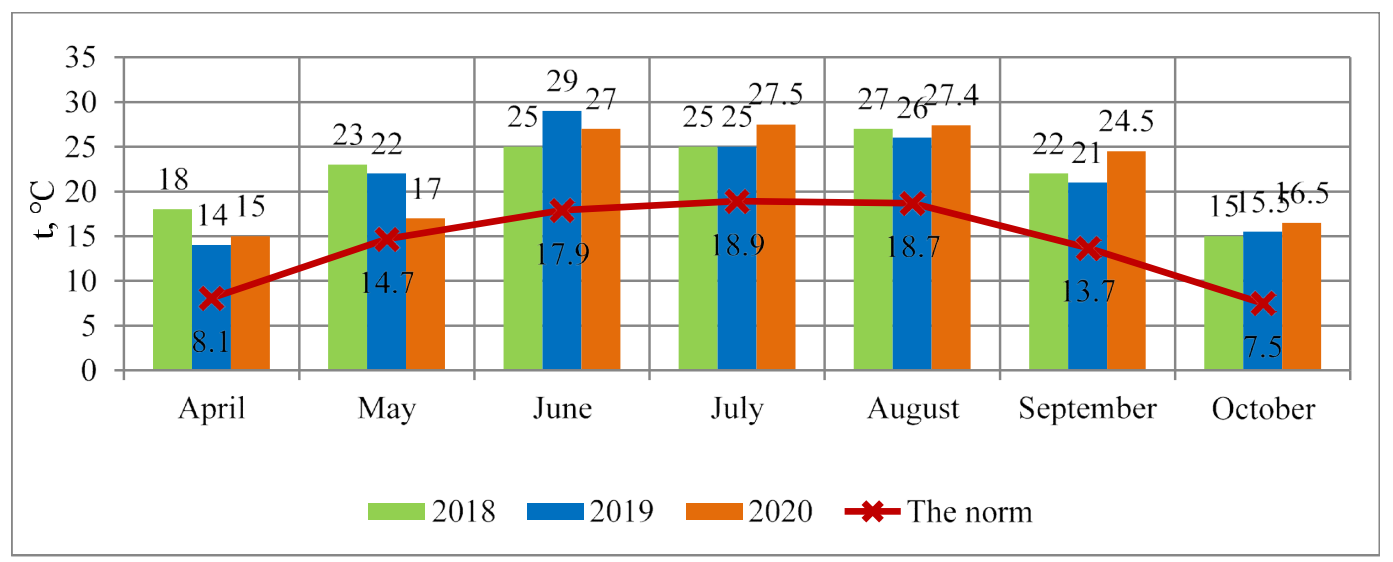

Fig. 1. Air temperature during field research (Research farm "Skvyrske" of IANM of the NA)

It is known that the optimum temperature for germination of soy seeds is $15-20{ }^{\circ} \mathrm{C}$; for flowering $-19-25^{\circ} \mathrm{C}$; for the formation of beans and seeds $-17-23{ }^{\circ} \mathrm{C}$; for maturation $-13-20{ }^{\circ} \mathrm{C}$. The average daily temperature at which the reproductive organs of soy are formed $-18-23{ }^{\circ} \mathrm{C}[24]$.

The weather conditions for growing soy during the study were within the normal range, despite the fact that the air temperature indicators exceeded the norm. The amount of precipitation during field research was quite contrasting and ranged from $8 \mathrm{~mm}$ (lower than the norm by $38 \mathrm{~mm}$ ) to $229 \mathrm{~mm}$ (above the norm by $128.9 \mathrm{~mm}$ ) (Fig. 2).

The varieties of soy plants Kent and Suzir'ja are characterized by medium resistance to drought. Given this, 2018 year was the least favorable for growing soy.

Climatic conditions perform both direct and indirect effects on the vital activity of microorganisms. At the same time, temperature and moisture are important components of environmental conditions that regulate the course of soil and biological processes. According to the results of retrospective analysis of literature, hydrothermal coefficient (HTC) determines the vital activity of soil organisms and the activity of soil biochemical processes. 


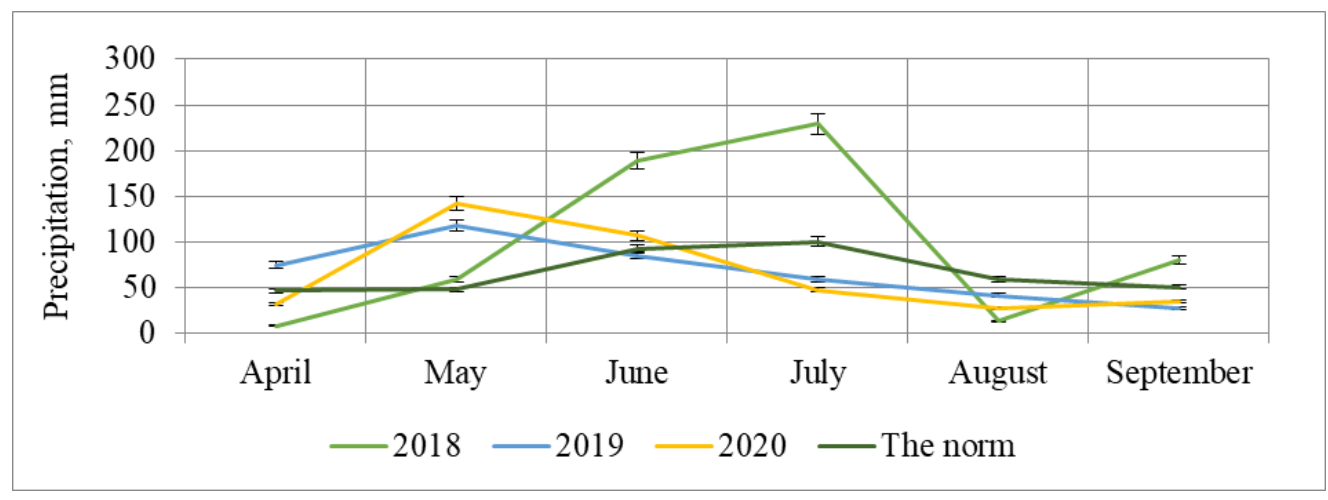

Fig. 2. The amount of precipitation during the field research (Research farm "Skvyrske" of IANM of the NA)

According to the calculated values of the HTC, it was established that the growing season of 2018 was wet enough (HTC 1.35), in 2019 - slightly arid (HTC 0.9) and in 2020 - wet enough (HTC 1) (Fig. 3).

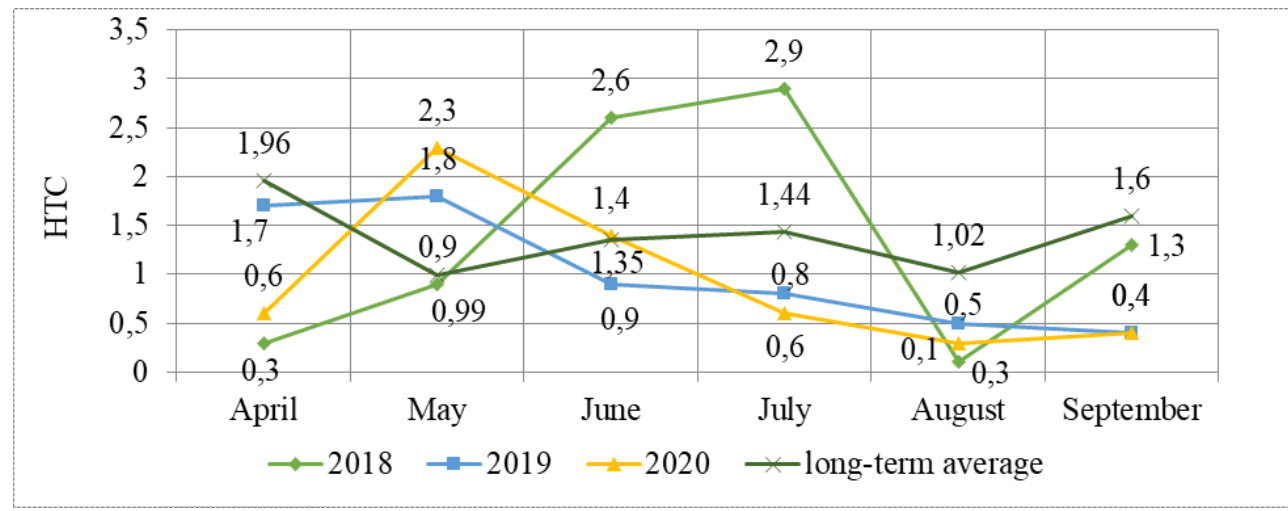

Fig. 3. Dynamics of indicators of hydrothermal coefficient (HTC) of the vegetation period in the years of research (Research farm "Skvyrske" of IANM of the NA)

According to the results of studies, it was found that there was a restrained formation of the number of micromycetes in the phase of shoots and maturation in 2018 during the action of the biopreparation Philazonit on plants of soy varieties Kent and Suzir'ja (Fig. 4)

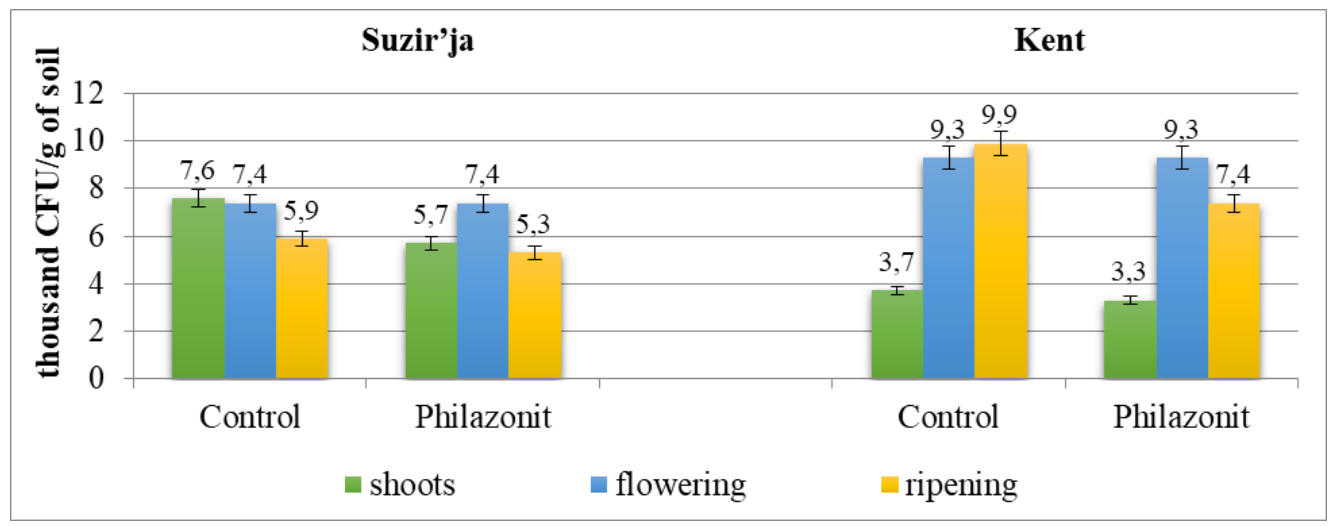

Fig. 4. The number (CFU/g of soil) of micromycetes in the rhizosphere soil of soybean plants of the varieties Suzir'ja and Kent under the action of the biological product Philazonit (2018) 
On plants of soy variety Suzir'ja in the phase of shoots, the number of micromycetes was less by 1.9 thousand CFU/g of soil and in the ripening phase - by 0.6 thousand CFU/g of soil compared to control. At the same time, on plants of soy variety Kent in the phase of shoots the number of micromycetes was less by 0.4 thousand CFU/g of soil, and in the ripening phase - by 2.5 thousand CFU/g of soil compared to control.

It was also found that in the flowering phase both on plants of soy varieties of Suzir'ja and Kent, the indicators of the number of CFU micromycetes were at the level of control and amounted to 7.4 thousand $\mathrm{CFU} / \mathrm{g}$ of soil and 9.3 thousand CFU/g of soil, respectively. This indicates the low efficiency of the Philazonit biopreparation, which may be due to exceeding temperature standards (by $+11.1^{\circ} \mathrm{C}$ ) and a large amount of precipitation, exceeding the norm by more than 2 times in the period from June to July (flowering phase), which caused the formation and development of phytopathogenic micromycetes and significantly reduced the effectiveness of Philazonit biopreparation on plants of soy varieties Kent and Suzir'ja in the flowering phase.

According to the results of the research, it was established that the formation of mycobiome in the rhizosphere of soy plants was suppressed during ontogenesis during the action of the Philazonit biopreparation on plants of soy varieties Suzir'ja and Kent in 2019 (Fig. 5).

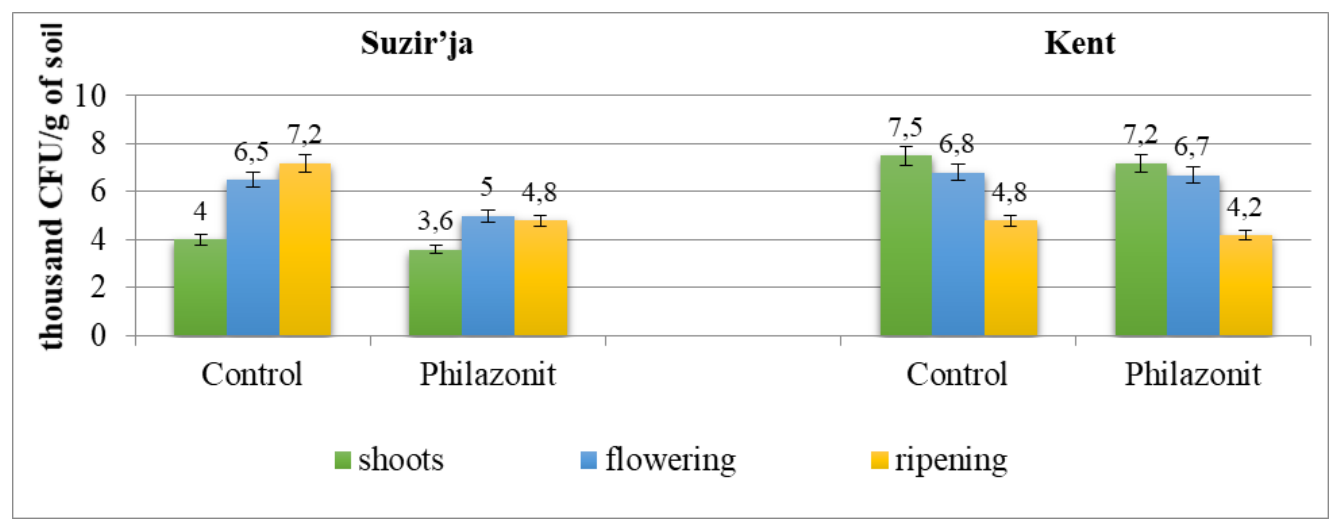

Fig. 5. The number of micromycetes (CFU/g of soil) in the rhizosphere of soybean plants Suzirya and Kent under the action of the biological product Philazonit (2019)

The smallest number of phytopathogenic micromycetes was observed in the phase of shoots on plants of soy varieties of Suzir'ja (3.6 thousand CFU/g of soil), and in the ripening phase on plants of soy of Kent variety (4.2 thousand CFU/g of soil). Similar results were obtained in 2020 (Fig. 6).

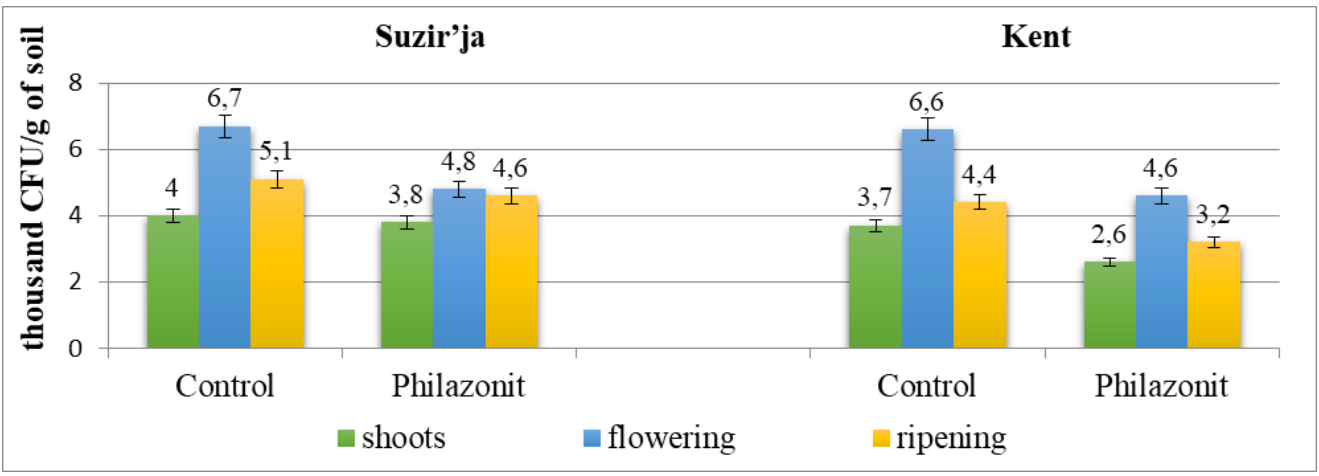

Fig. 6. The number (CFU/g of soil) of micromycetes in the rhizosphere soil of soybean plants of the varieties Suzir'ja and Kent under the action of the biological product Philazonit (2020) 
It should be noted that the most effect of biopreparation was found in the phase of shoots on both varieties, where the number of micromycetes in the mycobiome of rhizosphere plants of the soy Suzir'ja was 3.8 thousand CFU/g of soil, and on plants of soy of Kent variety - 2.6 thousand CFU/g of soil. The efficiency of the Philazonit biopreparation was high despite the fact that 2020 was characterized as wet enough (HTC 1) and the air temperature exceeded the norm. According to statistical analysis, presented in Table 1, the biopreparation Philazonit showed efficacy during the study in all phases of ontogenesis of plants and reduced the number of micromycetes in the mycobiome of the rhizosphere of the plants studied (Table 1).

Table 1

Dynamics of the number of micromycetes in the rhizosphere of soybean plants during the growing season

\begin{tabular}{|c|c|c|c|c|c|c|c|c|c|c|c|c|c|}
\hline \multirow{3}{*}{ Varieties } & \multirow{3}{*}{$\begin{array}{l}\text { Bioprepara- } \\
\text { tion }\end{array}$} & \multicolumn{9}{|c|}{$\begin{array}{l}\text { The average number of CFU in the rhizosphere of soybean plants, } \\
\text { thousand }\end{array}$} & \multicolumn{3}{|c|}{ The average } \\
\hline & & & 2018 & & & 2019 & & & 2020 & & & & \\
\hline & & shoots & flowering & $\begin{array}{l}\text { Ripen- } \\
\text { ing }\end{array}$ & shoots & $\begin{array}{l}\text { Flow- } \\
\text { ering }\end{array}$ & $\begin{array}{c}\text { ripen- } \\
\text { ing }\end{array}$ & Shoots & $\begin{array}{c}\text { flower- } \\
\text { ing }\end{array}$ & $\begin{array}{l}\text { ripen- } \\
\text { ing }\end{array}$ & shoots & $\begin{array}{l}\text { flower- } \\
\text { ing }\end{array}$ & ripening \\
\hline \multirow{2}{*}{ Suzir’ja } & Control & 65 & 62 & 49 & 35 & 54 & 60 & 35 & 56 & 44 & 45 & 57,3 & 51 \\
\hline & Philazonit & 47 & 62 & 36 & 26 & 44 & 41 & 25 & 40 & 32 & 32,6 & 48,7 & 36,3 \\
\hline insig- & over the years & & & & & & & & & & 19,5 & 9,8 & 21,4 \\
\hline $\begin{array}{l}\text { nificant } \\
\text { difference } \\
\mathrm{p}=0.05\end{array}$ & $\begin{array}{l}\text { for technolo- } \\
\text { gies }\end{array}$ & & & & & & & & & & 7,8 & 8,9 & 11,7 \\
\hline \multirow{2}{*}{ Kent } & Control & 37 & 78 & 83 & 62 & 57 & 40 & 31 & 55 & 37 & 43,3 & 63,3 & 53,3 \\
\hline & Philazonit & 28 & 78 & 62 & 52 & 45 & 26 & 22 & 42 & 22 & 34,0 & 55,0 & 36,7 \\
\hline insig- & over the years & & & & & & & & & & 11,5 & 16,0 & 17,1 \\
\hline $\begin{array}{l}\text { difference } \\
\mathrm{p}=0.05\end{array}$ & $\begin{array}{l}\text { for technolo- } \\
\text { gies }\end{array}$ & & & & & & & & & & 8,4 & 10,7 & 12,7 \\
\hline
\end{tabular}

Note: The difference is significant at the level of $p=0.05$

It should be noted that during the studies there was a correlation between the development of micromycetes and the hydrothermal coefficient - in the flowering phase $(r=0.8)$ and in the ripening phase $(r=0.9)$ except for the germination phase. A significant number of phytopathogenic micromycetes were isolated and identified from the rhizosphere of plants of soy varieties (Fig. 7).

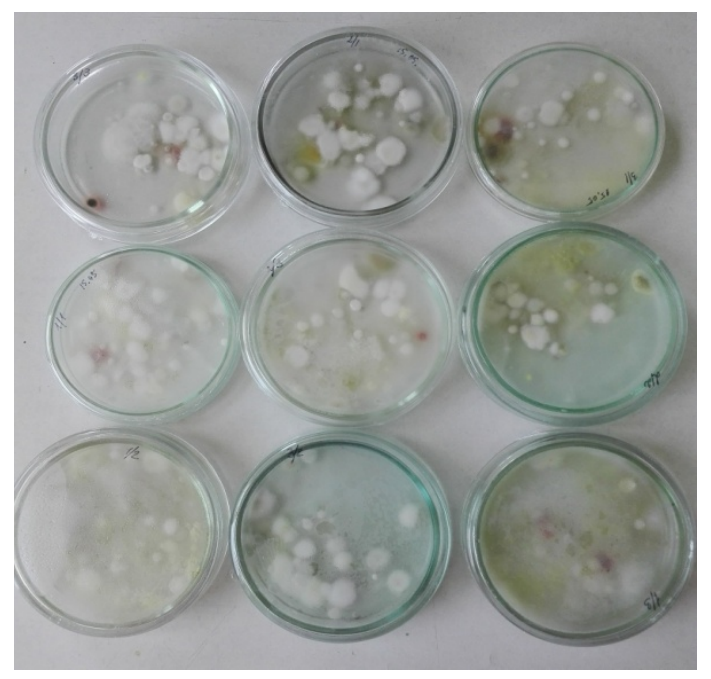

Fig. 7. The spectrum of micromycetes in the rhizosphere soil of soybeans plants of the Kent variety (5 days after seeding) 
The number of solates isolated from the rhizosphere of soybean varieties

Analysis showed that the species, belonging to four genera of micromycetes: Alternaria, Fusarium, Penicillium, Aspergillus in the rhizosphere of plants of both varieties of soy are dominated. In the rhizospheres of plants of the soy Suzir'ja variety the representatives of genus Penicillium (32.8\%) most often occurred. The smallest number of micromycetes were members of the genus Aspergillus (9.5\%). In the rhizosphere of plants of the Kent variety dominated by representatives of the genera Alternaria and Fusarium (35.6\% and $34.1 \%$ respectively). Representatives of the genus Penicillium were $15 \%$ and Aspergillus - $15.3 \%$ (Fig. $8 a, b$ ).

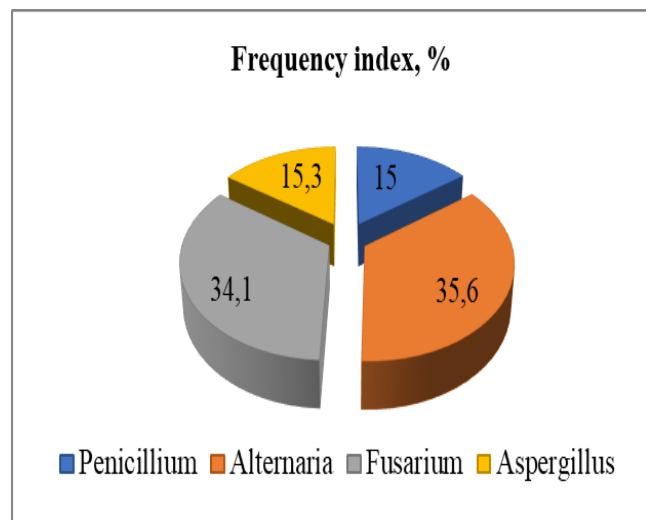

$\boldsymbol{a}$

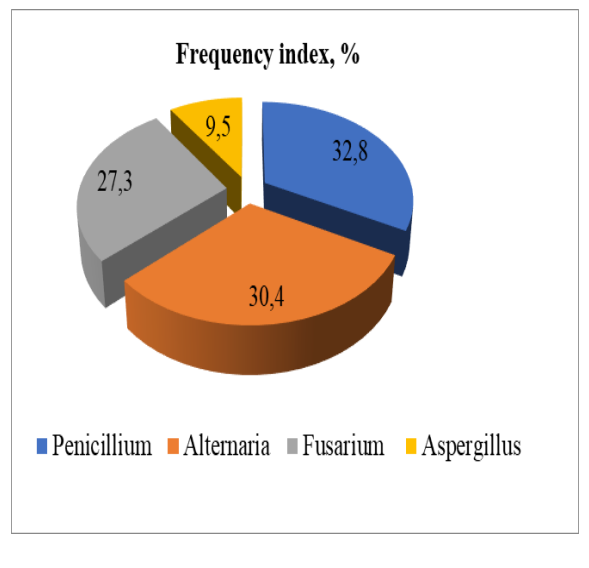

b

Fig. 8. Frequency of isolates isolated from the rhizosphere of soybean plants of varieties: $a$ - Suzir'ja; $b$ - Kent in the laboratory (2018-2020)

Biotic environmental factors significantly affect the number and dynamics of the population of phytopathogenic micromycetes in agrocenoses. One of the important factors is the selective pressure of cultivated plant varieties, which can affect the quantitative and qualitative indicators of the phytopathogenic background in agrocenoses.

Thus, it was established that in the rhizosphere of plants of soy varieties Suzir'ja and Kent the species of phytopathogenic micromycetes, belonging to the genera Alternaria, Fusarium, Penicillium, Aspergillus are dominated, which are factors of biological contamination of agrophytocenoses and decrease in product biosafety.

\section{Conclusions}

The possibility of regulating the number of phytopathogenic micromycetes in the mycobiome of soy plants by using biopreparation Philazonit has been experimentally proved, which will increase biosafety in soy agrocenoses and improve of the crop quality. According to statistical analysis, the biological product "Filazonit" has shown efficiency in research at all stages of plant ontogenesis.

It is proved that the representatives of genera: Alternaria, Fusarium, Penicillium, Aspergillus are dominated in the rhizosphere of plants of soy of both varieties. In the rhizospheres of plants of the soy Suzir'ja variety the representatives of genus Penicillium (32.8\%) most often occurred. In the rhizosphere of plants of the Kent variety dominated by representatives of the genera Alternaria and Fusarium (35.6\% and $34.1 \%$ respectively). Biotic environmental factors significantly affect the number and dynamics of the population of phytopathogenic micromycetes in agrocenoses. One of the important factors is the selective pressure of cultivated plant varieties, which can affect the quantitative and qualitative indicators of the phytopathogenic background in agrocenoses. 
Therefore, the control of microscopic fungal contamination of the main contaminants of biotic origin is relevant in the issue of feed safety. Systematic mycological studies of feed and feed materials for the presence of mold saprophytes will not only determine the taxonomic affiliation and identify toxin-forming species, but also contribute to the creation of a system of measures to prevent human poisoning and feed toxicosis in farm animals.

\section{Conflicts of interest}

The authors declare no conflicts of interest.

\section{References}

[1] Chetouhi, C., Bonhomme, L., Lasserre-Zuber, P., Cambon, F., Pelletier, S., Renou, J.-P., Langin, T. (2016). Transcriptome dynamics of a susceptible wheat upon Fusarium head blight reveals that molecular responses to Fusarium graminearum infection fit over the grain development processes. Functional \& Integrative Genomics, 16 (2), 183-201. doi: https://doi.org/10.1007/ s10142-016-0476-1

[2] Kyryk, M., Pikovskyi, M. (2017). Diahnostyka khvorob nasinnia horokhu ta soi. Propozytsiya, 1, 116-120. Available at: https:// propozitsiya.com/ua/diagnostyka-hvorob-nasinnya-gorohu-ta-soyi

[3] Xu, X., Nicholson, P. (2009). Community Ecology of Fungal Pathogens Causing Wheat Head Blight. Annual Review of Phytopathology, 47 (1), 83-103. doi: https://doi.org/10.1146/annurev-phyto-080508-081737

[4] Kobozev, I. V., Neustroev, I. I., Kobozeva, T. P., Mjakinkov, A. G., Sobolev, E. V. (2012). Features of chemical composition and optimization of Northern ecotype soybean seeds storage conditions (Glicine hispida Maxim.). Izvestiya TSKhA, 6, 101-109.

[5] Karlovsky, P., Suman, M., Berthiller, F., De Meester, J., Eisenbrand, G., Perrin, I. et. al. (2016). Impact of food processing and detoxification treatments on mycotoxin contamination. Mycotoxin Research, 32 (4), 179-205. doi: https://oi.org/10.1007/ s12550-016-0257-7

[6] Marroquín-Cardona, A. G., Johnson, N. M., Phillips, T. D., Hayes, A. W. (2014). Mycotoxins in a changing global environment - A review. Food and Chemical Toxicology, 69, 220-230. doi: https://doi.org/10.1016/j.fct.2014.04.025

[7] Svistova, I. D., Scherbakov, A. P., Frolova, L. O. (2004). Toksiny mikromitsetov chernozema: spektr antibioticheskogo deystviya i rol' v formirovanii mikrobnogo soobschestva. Pochvovedenie, 10, 1220-1227.

[8] Depev'yans'kiy, V. P., Kovalchuk, N. V. (2015). Protection and organic nutrition of soybean. Karantyn i zakhyst roslyn, 3, 6-8.

[9] Hryhorieva, O. M., Hryhorieva, T. M. (2015). Rol biopreparativ u tekhnolohiyi vyroshchuvannia soi. Visnyk Stepu, 12, 17-22.

[10] Melnyk, S. I., Zhylkin, V. A., Havryliuk, M. M., Snihovyi, V. S., Lisovyi, M. M. (2007). Rekomendatsiyi z efektyvnoho zastosuvannia mikrobnykh preparativ u tekhnolohiyakh vyroshchuvannia silskohospodarskykh kultur. Kyiv, 52.

[11] Pavlenko, H. V. (2012). Efektyvnist mineralnykh dobryv ta biopreparativ u tekhnolohiyi vyroshchuvannia soi v Lisostepu. Visnyk ahrarnoi nauky, 11, 68-69.

[12] Shevnikov, M. Y. (2011). Efektyvnist zastosuvannia biopreparativ ta mineralnykh dobryv pry vyroshchuvanni soi v umovakh nestiykoho zvolozhennia Lisostepu Ukrainy. Visnyk Poltavskoi derzhavnoi ahrarnoi akademii, 2, 14-18.

[13] Shevchuk M. I., Didkovska T. P. (2007). The efficiency of bacterial preparations use. Silskohospodarska mikrobiolohiya, 5, 129-135.

[14] Trufanov, O. (2013). Biopreparaty i soia: efektyvnyi zakhyst bez stresiv. Propozytsiya, 6, 48-49.

[15] Volkogon, V., Moskalenko, A., Dimova, S., Komok, M. (2012). Biokompleks na soe. Zerno, 3, 140-146.

[16] Shuvar, I. A., Ivanyshyn, V. V., Sendetskyi, V. M., Bunchak, O. M., Tsentylo, L. V. (2017). Ahroekolohichni osnovy polipshennia rodiuchosti gruntiv dlia staloho funktsionuvannia ahroekosystem, vyrobnytstva ekolohichno chystoi produktsiyi ta okhorony dovkillia v suchasnomu zemlerobstvi. Aktualni problemy pidvyshchennia rodiuchosti gruntiv ta zastosuvannia ahrokhimichnykh zasobiv v ahrofitotsenozakh. Lviv, 255-264.

[17] Belyavskaya, L. G., Belyavskiy, Y. V. (2016). Interaction of modern soybean varieties with biological preparations of complex action and their impact on the yield. Mikrobiolohichnyi zhurnal, 78 (3), 61-68.

[18] Sel'yaninov, G. (1928). O sel'skohozyaystvennoy otsenke klimata. Trudy po sel'skohozyaystvennoy meteorologii, 20, $165-177$.

[19] Zvyagintsev, D. G. (1991). Metody pochvennoy mikrobiologii i biohimii. Moscow: Izd-vo MGU, 304.

[20] Zvyagintsev, D. G. (1999). Rol' mikroorganizmov v biotsenoticheskih funktsiyah pochv. Strukturno-funktsional'naya rol' pochvy v biosfere. Moscow: GEOS, 113-121.

[21] MycoBank Database. Available at: https://www.mycobank.org/ 
[22] Kurakov, A. V. (2001). Metody vydeleniya i harakteristiki kompleksov mikroskopicheskih gribov nazemnyh ekosistem. Moscow: MAKS Press, 92.

[23] Markov, I. L., Pasichnyk, L. P., Hentosh, D. T. (2012). Praktykum iz osnov naukovykh doslidzhen u zakhysti roslyn. Kyiv, 156.

[24] Haziev, F. H. (1991). Fermentativnaya aktivnost' pochv agrotsenozov i perspektivy ee izucheniya. Pochvovedenie, $8,88-103$.

How to cite: Parfenuk, A., Havryliuk, L., Beznosko, I., Pasichnik, L., Turovnik, Y., Ternovyi, Y. (2021). Influence of Philazonit biopreparation on the mycobiome of soybean plants rhizosphere. EUREKA: Life Sciences, 3, 11-20. doi: https://doi.org/ 10.21303/2504-5695.2021.001874 